FACTA UNIVERSITATIS

Series: Linguistics and Literature Vol. 18, $\mathrm{N}^{\circ} 1,2020$, pp. 9-18

https://doi.org/10.22190/FULL2001009M

Original Scientific Paper

\title{
FANTASTIC STORYWORLDS AND TRANSFICTIONALITY OF LITERARY CHARACTERS
}

\author{
$U D C 82.0$
}

\section{Snežana M. Milosavljević Milić}

University of Niš, Faculty of Philosophy, Serbian Department, Niš, Serbia

\begin{abstract}
The interpretation of a literary character in the context of the distinction between the multiple storyworlds is connected with the phenomenon of "transfictionality" (Saint-Gelais 2005). When the same characters inhabit more possible worlds, they become travelling narrative individuals. If they originate as a 'transfer' of real historical persons through different fictional and non-fictional genres, "real individuals" represent extratextual versions (Margolin 1997, Dannenberg 2008). We refer to intertextual versions in case of variants of unreal individuals in different fictional genres. When we talk about variants of characters within a text created due to "travels" of characters from realistic to fantastic worlds, or through many virtual worlds, then we refer to intratextual versions. Our starting hypothesis is that transgressiveness of a character is an immanent characteristic of heroes in fantastic fictional worlds, regardless of the type of the fantastic. Modification appears as a compulsory factor of any type of transgression. The range and intensity of heroes' changes, as we know, show high variability, from the oldest and most explicit metamorphoses to partial or soft and barely visible modifications, from bodily transformations to psychological and mental variations, from sudden shapeshifting to gradual changes. Special intention will be paid to the counterfactual aspect of fantastic narrative world in the short stories by Radoje Domanović, Dejan Vukićević and Neil Gaiman. In line with that, we will briefly outline the intratextual relations which originate between the doubles of actual realistic fiction world and virtual/fantastic worlds. In that vein, one can consider the significant role of techniques of the fantastic in switching between storyworlds.
\end{abstract}

Key words: literary character, transfictional identity, storyworld, the fantastic

\footnotetext{
Submitted June 11, 2020; Accepted June 26, 2020

Corresponding author: Snežana Milosavljević Milić

University of Niš, Faculty of Philosophy

E-mail: snezana.milosavljevic.milic@ filfak.ni.ac.rs 


\section{INTRODUCTION}

The development of literary theory, which in the last several decades has called attention to the semantic domain of literary text, began with the concept of storyworld, which underwent theoretical proliferation mostly due to the Theory of Possible Worlds and various types of probabilism which occupied attention of philosophers and linguists, especially in the last century. As Marie-Laure Ryan $(1991,4)$ claims, "the semantic domain of the text is thus a collection of concatenated or embedded possible worlds". This theoretical platform found its applicative value mostly within the modern tendencies of postclassical and cognitive narratology.

The narratological turn has led to the revision and redefinition of many classical, mostly structuralistic viewpoints and results pertaining to nature of literature. ${ }^{1}$ The genre grouping of works belonging to the fantastic proved to be challenging for new approaches. At this point, we will not present the complex premises of the newer, cognitive theories of this genre; instead, we will point out that the focus on the semantic aspects of text resulted in the reinterpretation in genre theories. One of the canonical books on poetic aspects of the fantastic, Introduction à la littèrature fantastique by Tzvetan Todorov, is important for our topic. It has also proved to be inspirational and challenging for new approaches. This was perhaps best demonstrated by Nancy Traill, whose study Possible Worlds of the Fantastic: The Rise of the Paranormal in Fiction (1996) has shown the advances of the theory of possible worlds in redefining the fantastic writing. In his study from 1970, Todorov placed the fantastic between fantastic-uncanny and fantastic-marvelous, starting from the criterion of reception, i.e. the effect the text has on the reader regarding the degree of realization of narrated events. By excluding allegory and poetry from the fantastic, Todorov drew a boundary not only between genres but also between their storyworlds which commonly share the very quality that is considered to be differencia specifica of the fantastic: physical incompatibility with the real world. Contrary to Todorov, Traill claims that the fantastic is a universal aesthetic category, whose universality allows it to cut across genres and currents therefore, she formed a bridge between the fantastic worlds in stories of different genres and the literary-historical epochs. The typology of fantastic texts includes all three categories set by Todorov: the authenticated mode, the ambiguous mode and the disauthenticated mode, as well as the additional type, paranormal mode. Although Traill also determines the fantastic through the key criterion of physical incompatibility, the paranormal mode removes this sharp boundary: "In the paranormal mode FW is uniregional and the natural is infiltrated by the supernatural"(Ryan 1991, 9).

The theoretical consensus regarding the epistemological and/or ontological ${ }^{2}$ delimitation of fictional worlds based on their compatibility with the real world stresses the alethic component as the key differential characteristic of fictional worlds of the fantastic. Starting from the accessibility relations, Ryan $(1991,44)$ argues that "in its broadest and most intuitive use 'fantastic' is synonymous with transgression of E", when this E is related to the criterion of physical compatibility.

If the dualism forming the foundation of the alethic dimension of fictional worlds is connected to the principle of minimal departure (Ryan 1991, 48), which implicitly includes

\footnotetext{
${ }^{1}$ Some notable scholars of this orientation include David Herman, Monika Fludernik, Marie-Laure Ryan, Hillary Dannenberg, and Porter Abbott.

${ }^{2}$ Ryan defines the distinction between the natural and the supernatural in literature as an epistemological difference before postmodernism, and as an ontological difference since the postmodernism.
} 
the process of differentiation of worlds as a reception possibility, and if we simultaneously adopt the theoretical platform about plurality of worlds, the approach to fantastic worlds will undoubtedly be marked by transgression and different forms of fictional re-centering. The nature and degree/intensity of this transgression depend on a complex set of elements, and the most important elements are genre and predominating poetic and cultural paradigms. However, regardless of their specific and historical context-dependent characteristics, the differentiation of the fantastic as a different world implicitly assumes the transgressive relationship between the objects and the individuals as the main narrative entities of the worlds. This transgressiveness, as a dynamic cognitive reception component, indicates the interconnection and instability of fictional worlds, in contrast to the assumption of their stable or static nature. This view is strongly supported by characters as the most important entities of worlds within the story (Fludernik 2005). ${ }^{3}$

Our starting hypothesis is that transgressiveness of a character is an immanent characteristic of heroes in fantastic fictional worlds, regardless of the type of the fantastic. Modification appears as a compulsory factor of any type of transgression. The range and intensity of heroes' changes, as we know, show high variability, from the oldest and most explicit metamorphoses to partial or soft and barely visible modifications, from bodily transformations to psychological and mental variations, from sudden shapeshifting to gradual changes. ${ }^{4}$

As the new concept of a literary hero as an individual dwelling in the worlds of the story was also introduced to the narratology research by the theory of possible worlds, a thesis on transworld identity (tw) of the hero was also postulated as a result of this approach. According to Doležel (2008, 126), "Fictional persons of a natural world are possible counterpart of real persons, and their characteristics and abilities are fictional projections of attributes of real persons". The supernatural counterparts of the real worlds are inhabited by individuals of different alethic abilities. In this paper we will not refer to the extensive research in the last few decades dedicated to the phenomenon of tw identity of literary heroes, but we will provide a short overview of several notes relevant for our research topic.

When the same characters inhabit more possible worlds, they become travelling narrative individuals. According to Margolin (1997) and Dannenberg (2008), when they originate as a 'transfer' of real historical persons through different fictional and nonfictional genres, "real individuals" represent extratextual versions. In case of various variants of unreal individuals in different fictional genres, we refer to intertextual versions. When we talk about different variants of characters within a text that are created due to "travels" of characters from actual to virtual worlds, or through many virtual worlds, then we refer to intratextual versions. This typology can be made even more complex by various intertwining of the relations due to "multiple travels" of the characters - for example, extratextual and intertextual versions may have their intratextual doubles. A recent contribution to the typology of characters has been given by Marie-Laure Ryan. Ryan (2006, 659-644) distinguishes among three types of double relations: 1. characters who exist only within one copy: when found in one world, they are absent from the other; 2.

\footnotetext{
${ }^{3}$ Ryan $(1991,364)$ defines "storyworld through a static component which precedes the story and a dynamic component which captures the unfolding of the events". Individual characters who act as protagonists are part of the static component.

${ }^{4}$ This type of gradual changes was named morphing (Ryan 1999, 113).
} 
multiple individuals embodied and materialized in a different manner in each new world while their knowledge, memory and awareness of the identity remain a mutual feature and belong to the individual from the old world; 3 . individuals who possess only one copy in each world, but their memory is reversible, which causes the division of identity.

According to Ryan $(2006,656)$, "multiverse narrative overlaps with three types of story common in fantasy and science fiction, namely, the narrative of transworld exploration, the narrative of alternate history, and the time-travel narrative. But it cannot be reduced to any of them, because these story types exist in both a one-world and a many-worlds version." In line with these statements, Ryan $(2006,657)$ "uses transworld travel for narratives with a classical cosmology and cross-world travel for multiverse stories".

The phenomenon of tw relationships is further specified by the concept of transfictionality (tsf). According to Sant Gilley $(2008,612)$, who coined the term, "when two (or more) texts exhibit a transfictional relation they share elements such as characters, imaginary locations, or fictional worlds. Transfictionality may be considered a branch of intertextuality, but it usually conceals this intertextual link because it neither quotes nor acknowledges its sources. Instead, it uses the source text's setting and/or inhabitants as if they existed independently“.

For the transgressive nature of heroes of fantastic worlds, the transfictional identity of counterparts is at the second level (and following the logic, always metatextual), regardless of the placement of the previous native home of the hero in a mimetic or a supernatural world. This issue will be further discussed below, on the subject of a short story by Radoje Domanović.

Even when we put aside Doležel's $(2008,129)$ remark that "alethic potential of natural (human) persons is of greatest importance for fictional semantics", the transgressiveness of a character in fantastic worlds is not questioned. All three categories of inhabitants of supernatural worlds indicated by Doležel $(2008,127)$ support our thesis: "physically impossible beings: gods, ghosts, monsters", the so-called "hybrid persons" (heroes of myths, fables and legends) and "inanimate objects personified in the supernatural world" all achieve their (unnatural) markings due to deviations, which are recursively discovered by the reader during the process of naturalization ${ }^{5}$ during activation of a certain reference level ${ }^{6}$. Therefore, even in the cases when tsf relations are missing, when dichotomy between mimetic and supernatural worlds of the narrative universe is annulled, or when the anthropocentric attributes of the heroes are minimized, the very fact that a character is a narrative entity activates the cognitive protoframe as the epistemological frame which implies trans-world relationships. This is a basic, default position, which in a literary text or any genre is an integral part of much more complex, but also more concrete proto-portraits or native homes of the individuals.

This type of approach to the tw potential of characters in fantastic worlds ${ }^{7}$ is partially similar to the criterion of taxonomic compatibility introduced by Ryan regarding the accessibility relations between "actual world" and "textual actual world" (1991, 34). Furthermore, it may partially explain why the characters of fantastic worlds are so different

\footnotetext{
${ }^{5}$ Cf. Culler (1990, 197) and Ryan (1991, 48).

${ }^{6}$ The reference level is most commonly the real world, but there may be many other reference points, like cultural models, natural and artificially conventional etc.

${ }^{7}$ Anthropologically limited cognitive protoframe of a character is activated during the perception of the character in any genre or media. For example, the mimetic worlds of a story, such as those in the realistic literature of the second half of $19^{\text {th }}$ century, establish the equivalence between realistic and fictional worlds regarding this analogy (world of text as an accurate picture or copy of reality).
} 
from us, in contrast to the analogous heroes of mimetic genre we find very close. The modification of character, which is based on previously mentioned tw relations, may be also connected to the effect of middle genre, which was the only one to which the status of the fantastic was assigned by Todorov. If, according to Todorov $(2010,33)$, "fantastic assumes pulling the reader into the characters' world", the impossibility of clear delineation between that world and our world, caused by rationalization, may turn the tw journey into something unpleasant and dangerously reversible.

Here the term of modification was used in general sense, as a synonym for a change in general. However, if we consider Doležel's typology of tw relationships, "a fictional world can be linked to another world by three kinds of relations: expansion, modification and transposition" (Ryan 2013, 366). This counterpart relationship among the worlds also holds true for tw and tsf versions of characters in fantastic worlds. The aspects of tw versions of fantastic heroes may be also connected to the typological tripartite division of worlds according to the following three variables: (1) Distance from the actual world - a criterion which raises the question of how far one has to travel from the world made familiar to us by life experience for the notion of world to become inapplicable; (2) Size a variable which leads from the small worlds of micro-narratives to the large worlds of transmedia franchises; and (3) Ontological completeness - a variable which leads from worlds assumed to share the ontological status of the actual world, despite gaps in their representations, to worlds (or quasi-worlds)which present ontological gaps that cannot be filled by the principle of minimal departure (Ryan 2016, 11).

While the first and the third criterion may be effortlessly applied in the analysis of any tw aspect of fantastic characters, the criterion of size is much more useful in explaining their tsf status.

We will now present the applicative possibilities of previously postulated theoretical overviews through analysis of several texts belonging to different types of fantasy.

\section{TEXT ANALYSIS}

The short story Kraljević Marko po drugi put među Srbima, by the best-known Serbian satire author Radoje Domanović, is directing attention to the tw status of the hero in the very title. This literary work from the late $19^{\text {th }}$ century ${ }^{8}$ belongs to the genre of allegorical fantasy. The plot is simple and includes several chronologically arranged events: for 500 years, Serbs have been calling Marko Kraljević to come and free Kosovo; Marko rises from his grave and asks God for a permission to go to Serbia. In the new environment everything is unknown, while people are afraid of his appearance and declared him insane. After various disagreements and several murders, Marko was able to work as a street policeman for a short time, but finally he was placed into an asylum. The story ends with Marko's returning to the Other World and meeting God.

Marko Kraljević is the greatest hero in Serbian cultural and oral literary tradition, and the most famous epic hero of Serbian folk poems. His epic biography represents a hybrid symbiosis of various tw identities; he enters the epic world of folklore both as an

\footnotetext{
${ }^{8}$ In the note before the story was written, Domanović wrote: "Postoje razlozi za sablasnu priču. Oživelog ga suočiti sa današnjim čudima života. Na tome raditi.” (Timić 2009, 350).
} 
extratextual individual of the real historical person ${ }^{9}$ and as an intertextual multiplication of the hero of various poetic and genre matrices, where the predominant one is the literary profile of the typical epic hero ${ }^{10}$. Therefore, not only due to the counterfactual version in contrast to the realistic prototype ${ }^{11}$, but also due to various contaminations with other identity markers in various narrative worlds (poems, stories, legends, folk sayings), the character of Marko is paradigmatically transfictional. According to Nortrop Frye's taxonomy, he belongs to the third type of hero according to the degree of superiority in comparison to real persons, which provides him with significant potential for inhabiting supernatural fantastic worlds. As the epic storyworlds are not subject to mimetic narrative conventions, Marko's supernatural attributes and acts are an integral part of the referent world of an epic text.

The existence of this hero in the Domanović's storyworld is primarily authenticated through the key criterion of identification of tw and tsf identities: the personal name as a rigid designation. However, hero transgression now assumes overcoming various limits: spatial, temporal, ethical, cultural, political. Instead of seamless alterations that followed tsf counterparts of the epic Marko, in Domanović's work there is an antagonistic relationship between the worlds, so that Marko's tw counterpart is also drastically different. The mimetic storyworld, which is easily mapped in geographic, historical and ethnic classification (the storyline is placed in Serbia vaguely at the end of $19^{\text {th }}$ century), is countered by the opposite epic world and their intertwining in the referent world of text activates a hybrid fantastic world. In this case, the fantastic appears as a result of tw transition of the hero and strong interworld dissonance (similarly to humor), enabling Domanović to combine two registers: comical-satirical (perverting the high and the low) and fantastic (by widening the ontological boundaries of the world). Furthermore, the tsf vertical of Marko's character is additionally complicated by the genre context of allegory as a basically two-headed figure, as well as the antithetic pair of epic and satirical, which in the early phase of "folklore character of sjuzhet and genre" led to "double perception of life" (Frejdenberg 2011, 378, 379).

In addition to this transgenre re-signifying of the epic matrix, the author also builds the supernatural storyworld through other genre citations and thematic topoi which carry fantastic semantic potential. Such is the international motif of the dead returning to the world of the living, already known in the Serbian folklore fantasy through the motif of vampires, while in Domanović's work it was matched with the biblical motif of meeting with God on the Other World. At the beginning, it is mentioned that Marko rose from the grave and begged the Lord to allow him to go "down" among the Serbs. This beginning provided explicit thematic and concrete placement of the tw identity of the hero. ${ }^{12}$

The discrepancy between different worlds is manifested in changes in Marko's new tw identity. He becomes a special "alethic stranger" (Doležel 2008, 129) among his people,

\footnotetext{
${ }^{9}$ Marko Kraljević was the son of Vukašin Mrnjavčević, the ruler of one part of Serbian territory. After the victory of Turks in the battle on the river Marica in 1371, Marko became a Turkish vassal, and in that status he died in the battle at Rovine in 1396.

${ }^{10}$ There are extensive references on the epic literary biography of Marko Kraljević within the Serbian literature criticism. In this paper, we present the most pronounced epic attributes which have shaped his epic tsf identity.

${ }^{11}$ Epic glory status that does not match the historical fate of real Marko Kraljević.

${ }^{12}$ Numerous topoi are already a rich database of tsf heroes. In most cases, where the prototext is not explicitly referred to, the new version of the hero is leaning against the general cognitive frame of the topos, without the direct citation used for identification. This issue is also discussed by E. Panagiotidou in the cognitivenarratological discussion of intertextual relations in literature.
} 
and the degree of his modifications is proportional to the mismatch between his native home and the modern world he visits. The reminiscences of the international sjuzhet about a stranger among his own people are again supporting the complex nature of his multiplied tsf identity. In comparison to other characters, Marko's physical superiority is illustrated by the following citation: "Svaki mu brk koliko jagnje od po godine, a brada do pojasa, kao jagnje godišnjače. [....] sve oko sebe za čitavu glavu i više, nadvisio“ (Domanović 1974, 24). By using the epic paraphrase, not only did the narrator point out the supernatural attributes of the hero, but the same hyperbole also alluded to both physical and spiritual (moral) inferiority of court officials. This is supported by the description of the district official who is supposed to proclaim the verdict for Marko's misdeeds: "sreski načelnik, mali, žurav čovečić, upalih grudi, tupa pogleda, kašljuca pri govoru, a ruke mu kao štapići" (Domanović 1974, 24). The examples cited also indicate tsf potential of analogy and antithesis within the intratextual relations of characters; the character of district official thus becomes a reversed tsf version of Marko Kraljević, his negative counterpart who appears in the process of inertia transfer as an integral part of cognitive blending.

From the very beginning, Marko's return to the future was marked by the impossibility of his adaptation and numerous misunderstandings; the rider of a velocipede was identified as an enemy and decapitated, other people were addressed in decasyllable like an epic character would speak, he stood speechless due to amazement when he saw rifles and cannons. His deterioration in the new world, both physical and spiritual, unfolds simultaneously with his adaptation to that world. Instead of wine, he must drink water, instead of heroic battles, he must be occupied by minor and insignificant tasks (watering and weeding the garden, making knives and brushes), then he becomes a street policeman, disguised so that he is not recognized, while the peak of Marko's character's degradation is when he is declared insane and placed into an asylum. The storyteller manages this perverting of the hero's identity masks precisely due to his tsf status as the background protobiography. It belongs to the cognitive framework, contextually much wider than the explicit citational textual clues (name of character, decasyllable verses, and lexical fund) which function as triggers to the prototypic version. The tsf status of Marko is paralleled by that of his horse Šarac, as his tw pathway is marked by similar regressive steps: in poems, a winged horse faster than a fairy, in the new world Šarac is but an old nag, "sama koža i kost", left to dream about the former golden times.

Transposition of the hero to another world does not only initiate his alteration, but the reversibly also includes his protoversion. Another intratextual version of Marko's character appears in this transfer, and its mimetic potential was used by the author in order to criticize his contemporary society. It turns out that constant calling for Marko to return to his people and revenge Kosovo is just a rhetoric gesture, so this virtual counterpart of Marko's character (constantly present in the awareness of descendantcompatriots) is shown as empty of meaning and ideology, just a mere convention. Finally faced with himself as a (textual) construction which exists in the memory of others, completely de-authenticated, without the referent fullness, Marko disappointedly returns to the Other World and, in before God, renounces his people.

The fantastic world formed by fusion of two models of storyworld through the tw journey of the main character has a pronounced critical and satirical function in Domanović's short story. The dethroning of the highly mimetic type of hero by his placement into low mimetic context leads to grotesque shapeshifting and devaluation of the real world, which has unrealistic outlines suggesting various forms of societal deviations targeted by the author's 
satire. This ideological instrumentalization of the fantastic paradoxically shows all porosity of distinction between the real and the impossible which may be absorbed by the potential of fictional worlds.

In the analyzed Domanović's short story, tw and tsf status of the hero are followed by a clear distinction between the worlds, enabling easier readability/differentiation of the fantastic world. In modern literature, where fictional worlds also contain the fantastic ones, the tw character of the hero is not always so explicitly differentiated in meaning or rhetorically (figuratively) re-signified. We will illustrate this with texts starting with the "primarily double structure of the alethic type of mythological world (Doležel 2008, 139), creating, according to Doležel $(2008,195)$, not a "heterogeneous world" but a new type of supernatural "hybrid world". However, although Doležel $(2008,195)$ claims that in the hybrid world the physically possible and physically impossible events are "spontaneously and randomly generated within the same domain", we cannot completely accept his thesis that in this type of world "the boundary between the natural and the supernatural domain is removed, and their modal opposition is neutralized" so that the "alethic conditions of the hybrid world demand that we should abandon the opposition natural/supernatural". Actually, the latent, implicit existence of this opposition forms the foundation of the cognitive frame enabling the reception of the fictional world as the hybrid world or as a "secularized counterpart of the classical myth" as Doležel $(2008,203)$ rightfully claims regarding the literature of $20^{\text {th }}$ century.

For example, the short story Kentaur by Dejan Vukićević introduces the supernatural world gradually, with transgression of the hero through mythological-fantastic citation. Instead of a sudden metamorphosis, the re-signification of the new identity is acquired gradually, through the strategy of "morphing" (Ryan 1999, 113). The transition from realistic to supernatural was again implicitly strengthened by the cognitive frame triggered by the tsf status of the mythical hero. His arrival (or rather, arrival of his tsf version) ${ }^{13}$ to the storyworld, which until that point is limited by otherwise realistic coordinates, is a crucial factor of mimetic destabilization of this world and the change in its ontological status.

The cognitive transfer enabling a mythological subtext was also used to construct the supernatural world of Neil Gaiman's short story Problem sa Kasandrom. At the beginning just an imaginary person inside the mind of a shy teenager, a girl named Cassandra later becomes an integral, materialistic, physical part of this real world in a naturally inexplicable way, replicating the anticipated route of his destiny. This modern version of the mythical prophetess has an important role in the interpretation of the semantic base of this story, but it is also a marker of a tension between the "disauthenticated" and the "supernatural domain" (Traill 1996, 14), as she also simultaneously appears as her intratextual counterpart due to the hero's journey through the internal (mental) subworlds.

The possibilities of tw alterations of characters in the fantastic worlds may be also discussed without a clear tsf citation. In another Gaiman's short story Narandžasta there is an opposite alteration as now the female hero changes her materialistic, physical form into immaterial reflections due to the effect of self-tanning cream. Both examples from modern literature call attention to the importance of bodily metamorphoses as more visible indicators of tsf or tw alterations. The myths on metamorphoses, the use of a mask as an accompanying prop, or most commonly a combination of bodily characteristics

\footnotetext{
${ }^{13}$ In spite of the citation in the title, the story was not reproduced completely and the mythological sjuzhet is varying; the supernatural being is born after the owner of the house has a sexual relationship with a cow.
} 
with parts of animal body, support this thesis. Unlike bodily changes, mental changes may always be naturalized, no matter how radical they may be, as we know from innumerous examples in psychologically well-shaped characters in literature.

\section{CONCLUDING REMARKS}

In a wider genre classification, the literary texts analyzed in this paper may be taken as examples of allegorical, mythological and psychological fantasy, which is present as a layer in stories by N. Gaiman. The more detailed literary-historical and theoretical discussion of these fantastic subtypes could very well specify the role of tw and tsf statuses of heroes. In this paper, at least in broad remarks, we tried to point out the tendencies and main methodological assumptions of such identity multiplications.

\section{REFERENCES}

Alber, Jan. 2009. "Impossible Storyworlds - and What to Do with Them". Storyworlds: A Journal of Narrative Studies, Vol. 1 (2009), 79-96.

Dannenberg, Hillary P. 2008. Coincidence and Counterfactuality, Plotting Time and Space in Narrative Fiction. Lincoln and London: University of Nebraska Press.

Doležel, Lubomir. 2008. Heterokosmika, Fikcija i mogući svetovi. Translated by Snežana Kalinić. Beograd: Službeni glasnik.

Domanović, Radoje. 1974. Satire. Beograd: Nolit.

Fludernik, Monika. 2005. Towards a "Natural" Narratology. London, New York: Routledge.

Frejdenberg, Olga M. 1997. Poetika sižea i žanra. Translated by Radmila Mečanin. Novi Sad, Sremski Karlovci: Izdavačka knjižarnica Zorana Stojanovića.

Gejmen, Nil. 2017. Upozorenje o sadržaju, Translated by Draško Roganović. Beograd: Laguna.

Kaler, Džonatan. 1990. Strukturalistička poetika, Translated by Milica Mint. Beograd: Srpska književna zadruga.

Margolin, Juri. 1997. "Jedinke u narativnim svetovima: jedna ontološka perspektiva“, Reč, 30. 88-100.

Panagiotidou, Maria-Erini. 2011. "A cognitive approach to intertextuality: The case of semantic intertextual frames". Newcastle Working Papers in Linguistics 17, 173-187.

Pavel, Thomas G. 1986. Fictional Worlds. Cambridge. Ma: Harvard University Press.

Ryan, Marie - Laure. 1991. Possible Worlds: Artificial Intelligence and Narrative Theory, Bloomington: Indiana University Press.

Ryan, Marie-Laure. 1999. "Cyberage Narratology: Computers, Metaphor, and Narrative“. In Narratologies: New Perspectives on Narrative Analysis. Edited by David Herman, 113-141. Ohio: State University Press.

Ryan, Marie-Laure. 2006. "From Parallel Universes to Possible Worlds". Poetics Today, 27: 4. 633-674.Duke University Press, Durham, North Carolina.

Ryan, Marie-Laure. 2013. “Transmedial Storytelling and Transfictionality”. Poetics Today, 34: 3. 361-388. Duke University Press, Durham, North Carolina.

Ryan, Marie-Laure. 2016. "Texts, Worlds, Stories. Narrative Worlds as Cognitive and Ontological Concept". In Narrative Theory, Literature, and New Media. Narrative Minds and Virtual Worlds, edited byMari Hatavara, Matti Hyvärinen, Maria Mäkelä, Frans Mäyrä. 11-28. Routledge.

Saint-Gelais, Richard. 2008. "Transfictionality". In D. Herman, M. Jahn. M-L. Ryan, (eds.), Routledge Encyclopedia of Narrative Theory, Routledge.

Timić, Bojan. 2009. "Domanović i Pirot". In Pirotski zbornik, 34 edited by Ivko Jovanović, 346-352. Pirot: Narodna biblioteka.

Todorov, Cvetan.2010. Uvod u fantastičnu književnost. Translated by Aleksandra Mančić, Beograd: Službeni glasnik.

Traill, Nancy.1996. Possible Worlds of the Fantastic: The Rise of the Paranormal in Fiction.Toronto, Buffalo, London: University of Toronto Press.

Vukićević, Dejan. 2002. Aleja bizarnih kipova. Beograd: Rad. 


\section{FANTASTIČNI SVETOVI PRIČE I TRANSFIKCIONALNI KNJIŽEVNI LIKOVI}

Tumačenje književnog lika u kontekstu distinkcije aktuelnog $i$ virtuelnog narativa povezano je sa fenomenom "transfikcionalnosti“ (Saint-Gelais 2005). Kada isti likovi naseljavaju više mogućih svetova, oni postaju putujuće narativne jedinke koje se tipološki mogu razvrstati na ekstratekstualne, intertekstualne $i$ intratekstualne verzije. Mari-Lor Rajan izdvaja tri tipa parnjačkih odnosa: 1) karakteri koji egzistiraju samo u jednoj kopiji i, kada su u jednom svetu, odsutni su iz drugog; 2) multiplikovane individue koje se otelotvoruju i materijalizuju drugačije u svakom novom svetu, dok njihova znanja, sećanja $i$ svest o identitetu ostaju zajednička i pripadaju jedinki iz starog sveta; 3) individue imaju samo po jednu kopiju u svakom svetu, ali je njihovo sećanje reverzibilno što uzrokuje raspolućenost identiteta (Ryan 2006). Naša polazna pretpostavka je da je transgresivnost lika imanentno svojstvo junaka u fantastičnim fikcionalnim svetovima bez obzira na to o kom tipu fantastike je reč. Analiza izvornih tekstova, pripovedaka R. Domanovića, D. Vukićevića i N. Gejmena pokazuje da je raspon $i$ intenzitet promene junaka visoko varijabilan: od najeksplicitnijih metamorfoza do parcijalnih ili mekih i jedva vidljivih modifikacija, od telesnih transformacija do psiholoških $i$ mentalnih varijacija, od naglih preobražaja do postepenih promena. Dok je u Domanovićevoj pripoveci transfikcionalni status junaka praćen jasnom distinkcijom među svetovima, što omogućava veću čitljivost/diferencijaciju fantastičnog sveta, u savremenoj književnosti, čiji fikcionalni svetovi sadrže i one fantastične, transsvetovni identitet junaka nije uvek tako eksplicitno značenjski diferenciran ili retorički (figurativno) preoznačen. Analizirani književni tekstovi mogu se u širem žanrovskom ključu uzeti i kao primeri alegorijske, mitološke i psihološke fantastike.

Ključne reči: književni junak, transfikcionalni identitet, svet priče, fantastika 